\title{
Суслов В.В. \\ К 100-ЛЕТИЮ СО ДНЯ \\ РОЖДЕНИЯ ПРОФЕССОРА РУДОЛЬФА ФРАЯ
}

22 Августа 2017 года исполняется 100 лет со дня рождения выдающегося немецкого анестезиолога послевоенного периода.

Профессор Рудольф Фрай является пионером и основоположником анестезиологии в ФРГ. Рудольф Фрай закончил медицинский факультет Гайдельбергского университета в 1943 году и был направлен в армию. Как молодой врач, занимался, в основном, проведением наркоза во время операций в военном госпитале. В послевоенные годы (1945-1949) изучал хирургию в клинике профессора К. Бауэра (Гайдельберг), и в 1949 году получил диплом врачахирурга. В это время начала развиваться торакальная хирургия. Профессор К. Бауэр (Гайдельберг) - человек прогрессивных взглядов, стремился идти в ногу с мировыми тенденциями развития хирургии. Следуя этой цели, он поставил задачу освоения торакальных операций. Однако для этого было необходимо освоение эндотрахеального наркоза.

Учитывая незаурядные способности молодого врача Р. Фрая, профессор направил его на длительную стажировку в ведущие клиники Европы и Америки.

Следует отметить, что Германия за время Второй мировой значительно отстала в развитии анестезиологии по сравнению с такими странами как Англия и Америка, где уже во многих клиниках проводились операции на легких и сердце под эндотрахеальным наркозом.

В 1950 году Р. Фрай организует первое в Западной Германии отделение анестезиологии и интенсивной терапии при хирургической клинике Гайдельбергского университета. Это отделение стало базой для подготовки врачей-анестезиологов, называемых тогда наркотизаторами.

В 1952 году Фрай защитил докторскую диссертацию и получил звание профессора. В этом же году он организовал издание первого немецкоязычного журнала по анестезиологии, который стал в дальнейшем печатным органом трех анестезиологических обществ: Германии, Австрии и Швейцарии.

В 1953 году Р. Фрай добивается выделения анестезиологии в самостоятельную специальность и организует первое в Германии общество анестезиологов. В 1955 году он опубликовал свой фундаментальный труд «Anaesthesiologia und wiederbecebung», который был переведен на русский язык и стал первым учебным пособием для преподавания в Украине.

Благодаря своему энтузиазму, контактности и открытости он установил широкие научные связи с ведущими анестезиологами мира. Интенсивно сотрудничал с такими выдающимися анестезиологами как Р. Макинтош (Оксфорд), Ж. Ласснер (Франция), В. Хюгин (Швейцария), О. Майергофер (Австрия), Т. Горд (Швеция), П. Сафар. Он так сформулировал свой девиз: «Анестезиологи - это единая семья независимо от национальности и гражданства».

Весьма плодотворным было его сотрудничество с Питером Сафаром в сфере организации медицины катастроф. Р. Фрай впервые в Германии применил специально 
оборудованный вертолет для оказания медицинской помощи при катастрофах и назвал его «летающим автомобилем».

В 1960 году Р. Край был приглашен в город Майнц для организации первой в ФРГ кафедры анестезиологии в университете Гуттенберга. В 1962 году на базе кафедры был создан «Институт анестезиологии и интенсивной терапии», который существует до настоящего времени. В 1971 году в Майнце Рудольф Фрай возглавил «Клуб Майнца», сегодня это Ассоциация стихийных бедствий, оказывающая помощь во время катастроф по всему миру.

Научные и профессиональные контакты не ограничивались лишь представителями западного мира. В 1970-е годы он проявил большой интерес к развитию анестезиологии в Советском Союзе. Во времена существования «железного занавеса» между Западом и Востоком, контакты СССР с Западом были очень ограничены. В 1971 году профессору Р. Фраю удалось прорваться через занавес и установить контакты с советскими анестезиологами. Министерство здравоохранения дало согласие на посещение трех городов - Москвы, Ленинграда и Донецка. Он посетил тех, кого знал лично: в Москве профессоров В.А. Неговского и Е.А Дамир, в Ленинграде профессора Ю.Н. Шанина, в Донецке - профессора В.В.Суслова.

Профессор Р. Фрай возглавил издание книг под названием «Анестезиология и интенсивная медицина» (было опубликовано более 50 томов этой серии). Он, как главный редактор, регулярно бесплатно присылал эти книги, что позволило анестезиологам Украины знакомиться с достижениями современной анестезиологии.

После смерти профессора Рудольфа Фрая в 1981 году немецким научным обществом анестезиологов учреждена медаль его имени, которой ежегодно, с 1990 года, награждаются ученые за существенный вклад в развитие современной анестезиологии. 